\title{
Penentuan Bahan Makanan Untuk Itik Petelur Menggunakan Algoritma Genetika
}

\author{
Imam Fahrur Rozi' ${ }^{1}$ Annisa Taufika Firdausi², Tahta Reza Rahmadhany ${ }^{3}$ \\ 1,2,3 Program Studi Teknik Informatika, Jurusan Teknologi Informasi, Politeknik Negeri Malang \\ ${ }^{1}$ imam.rozi@polinema.ac.id, ${ }^{2}$ annisa.taufika@polinema.ac.id, ${ }^{3}$ tahtareza98@gmail.com
}

\begin{abstract}
Abstrak
Itik berperan sebagai penghasil telur dan daging. Tingkat produktivitas itik lokal Indonesia baik telur maupun daging masih rendah dan berpeluang untuk ditingkatkan. Produktivitas ternak dipengaruhi oleh faktor pakan, manajemen dan pembibitan. Permasalahan yang sering dihadapi peternak adalah ketersediaan pakan, pakan yang diberikan memiliki kandungan nutrisi rendah. Jika penentuan pakan yang diberikan tidak sesuai dengan standarisasi kebutuhan itik maka yang terjadi adalah itik petelur tidak mencapai kondisi yang optimal seperti kurangnya nafsu makan, mudah terserang penyakit, dan tidak lincah. Bahkan yang lebih fatal bisa mengakibatkan kematian pada itik. Dari ulasan tersebut dapat diketahui pembuatan pakan itik dengan memperhatikan nutrisi perlu dilakukan. Permasalahan penentuan bahan pakan ternak itik petelur dapat diselesaikan dengan algoritma genetika, dikarenakan algoritma genetika memiliki kelebihan dalam menghasilkan output dengan tetap memperhatikan faktor nutrisi. Nutrisi pada itik petelur yang harus dipenuhi antara lain protein kasar, energi, metionin, lisin, kalsium, dan fosfor yang memiliki masing-masing nilai standarnya. Proses algoritma genetika dimulai dengan inisialisasi populasi, menghitung fitness, seleksi, crossover, mutasi, dan evaluasi. Berdasarkan penelitian yang telah dilakukan, untuk mengukur kualitas solusi pada permasalahan penentuan bahan makanan untuk itik petelur yaitu dengan melihat nilai fitness. Parameter algoritma genetika memiliki pengaruh terhadap nilai fitness yang dihasilkan. Pengujian parameter algoritma genetika dilakukan dengan mengkombinasikan cr dan $\mathrm{mr}$, yang terbaik terdapat pada kombinasi cr 0,7 dan $\mathrm{mr} 0,2$ dengan rata-rata nilai fitness 2,960 . Ukuran populasi yang baik adalah 35 dengan nilai fitness 2,706. Pengujian jumlah generasi dihasilkan fitness terbaik 2,804 terdapat pada generasi 20.
\end{abstract}

Kata kunci : algoritma genetika, bahan makanan, itik petelur.

\section{Pendahuluan}

Itik berperan sebagai penghasil telur dan daging. Sebanyak $19,35 \%$ dari 793.800 ton kebutuhan telur di Indonesia diperoleh dari telur itik. Tingkat produktivitas itik lokal Indonesia baik telur maupun daging masih rendah dan masih berpeluang untuk ditingkatkan. Setioko (1990) melaporkan bahwa tingkat produktivitas itik petelur yang digembalakan hanya sekitar 26,9 - 41,3\%, sedangkan tingkat produksi telur itik terkurung dapat mencapai $55,6 \%$ (Ketaren, 2002). Ini membuktikan tingkat produktivitas itik petelur terkurung lebih tinggi dari produktivitas itik gembala karena mutu pakan yang diberikan lebih baik. Rendahnya produksi telur tersebut sebagian disebabkan oleh pakan yang tidak memadai. Produksi telur itik gembala tersebut dapat ditingkatkan dari 38,3\% menjadi $48,9 \%$ dengan memberi pakan tambahan (Ketaren, 2002). Juga dilaporkan bahwa bobot telur meningkat dari ratarata 66,9 menjadi 71,1 gram dengan pemberian pakan tambahan 24 gram tepung kepala udang kepada itik gembala selama musim kering atau dengan memberi pakan tambahan tepung ikan dan vitamin-mineral premix.
Produktivitas ternak dipengaruhi oleh faktor pakan, manajemen dan pembibitan. Permasalahan yang sering dihadapi peternak adalah ketersediaan pakan, yang mana pakan yang diberikan pada ternak memiliki kandungan nutrisi rendah. Sebagai contoh adalah limbah hasil samping pertanian, industri pertanian dan pangan. Limbah pertanian berasal dari limbah tanaman pangan seperti jerami jagung, jerami padi dan lain-lain. Kandungan nutrisi yang rendah akan mempengaruhi kecernaan pakan dan ketersediaan nutrisi, sehingga produktivitas ternak juga rendah (Syururi, Hidayat, \& Dewi, 2019). Jika penentuan pakan yang diberikan tidak sesuai dengan standarisasi kebutuhan itik maka yang terjadi adalah itik petelur tidak mencapai kondisi yang optimal seperti kurangnya nafsu makan, mudah terserang penyakit, dan tidak lincah. Bahkan yang lebih fatal lagi bisa mengakibatkan kematian pada itik tersebut. Dari ulasan tersebut, dapat diketahui bahwa pembuatan pakan itik dengan memperhatikan nutrisi perlu dilakukan. Dengan hadirnya sebuah sistem yang dapat membantu peternak itik maupun masyarakat awam dalam melakukan penentuan bahan makanan dari berbagai pilihan bahan makanan ternak yang ada, tentu akan mempermudah peternak 
dalam mengelola hewan ternak miliknya khususnya dalam pemberian pakan.

Permasalahan penentuan bahan makanan untuk ternak itik petelur dapat diselesaikan dengan algoritma genetika, hal itu dikarenakan algoritma genetika memiliki kelebihan dalam menghasilkan output dengan tetap memperhatikan faktor nutrisi. Nutrisi pada itik petelur yang harus dipenuhi antara lain protein kasar, energi, metionin, lisin, kalsium, dan fosfor yang memiliki masing-masing nilai standarnya. Penggunaan konsep evolusi biologi akan menghasilkan suatu output berupa bahan pakan yang sebaiknya dikonsumsi untuk memenuhi kebutuhan nutrisi (Syururi, Hidayat, \& Dewi, 2019). Salah satu penelitian yang menggunakan algoritma genetika telah dilakukan pada objek penentuan komposisi bahan makanan bagi penderita gagal ginjal akut (Lestari, et al., 2017). Dari penelitian tersebut dihasilkan kesimpulan bahwa algoritma genetika dapat digunakan untuk menentukan komposisi makanan yang sesuai untuk kebutuhan gizi penderita gagal ginjal akut.

Pada penelitian ini akan dikembangkan sistem penentuan bahan makanan untuk itik petelur menggunakan algoritma genetika. Sistem menyediakan data tentang kebutuhan nutrisi itik petelur, serta daftar kandungan nutrisi pada beberapa bahan makan ternak yang kemudian akan diproses dengan algoritma genetika hingga menghasilkan keluaran berupa rekomendasi kombinasi bahan makanan untuk itik petelur. Kombinasi tersebut terdiri dari beberapa bahan makan ternak, semisal terdiri dari lima bahan yaitu dedak padi, menir, jagung, bungkil kelapa, dan ikan kering. Proses algoritma genetika akan dimulai dengan pembangkitan populasi awal (inisialisasi populasi), menghitung fitness, seleksi, crossover, mutasi, dan evaluasi. Pada tahap seleksi menggunakan metode seleksi roulette wheel selection. Teknik crossover yang digunakan adalah single point crossover. Lalu, proses mutasi menggunakan metode random mutation. Serta pada proses evaluasi digunakan populasi model generational replacement, dan untuk mempertahankan individu terbaik pada suatu generasi diperlukan elitisme.

\section{Sumber Bahan Makan Ternak}

Berdasarkan kandungan serat kasarnya bahan makanan ternak dapat dibagi kedalam dua golongan yaitu bahan penguat (konsentrat) dan hijauan (Ilmu dan Teknologi Pakan Fakultas Peternakan IPB, 2012). Konsentrat dapat berasal dari bahan pangan atau dari tanaman seperti serealia (misalnya jagung, padi atau gandum), kacang-kacangan (misalnya kacang hijau atau kedelai), umbi-umbian (misalnya ubi kayu atau ubi jalar), dan buah-buahan (misalnya kelapa atau kelapa sawit). Konsentrat juga dapat berasal dari hewan seperti tepung daging dan tepung ikan. Disamping itu juga dapat berasal dari industri kimia seperti protein sel tunggal, limbah atau hasil ikutan dari produksi bahan pangan seperti dedak padi dan pollard, hasil ikutan proses ekstraksi seperti bungkil kelapa dan bungkil kedelai, limbah pemotongan hewan seperti tepung darah dan tepung bulu, dan limbah proses fermentasi seperti ampas bir. Hijauan dapat berupa rumput-rumputan dan leguminosa segar atau kering serta silase yang dapat berupa jerami yang berasal dari limbah pangan (jerami padi, jerami kedelai, pucuk tebu) atau yang berasal dari pohon-pohonan (daun gamal dan daun lamtoro).

Klasifikasi berdasarkan kandungan gizinya bahan makanan ternak dapat dibagi atas sumber energi (misalnya dedak ubi kayu), sumber protein yang berasal dari tanaman (misalnya bungkil kedelai dan bungkil kelapa) dan sumber protein hewani (tepung darah, tepung bulu dan tepung ikan). Selain sumber protein dan sumber energi, beberapa bahan makanan dapat digolongkan sebagai sumber mineral (misalnya tepung tulang, kapur dan garam), serta sumber vitamin (misalnya ragi dan minyak ikan). Beberapa bahan seperti antibiotika, preparat hormon, preparat enzim, dan buffer dapat digunakan untuk meningkatkan daya guna ransum. Bahan-bahan tersebut digolongkan dalam pakan imbuhan (feed aditif). Pengelompokan yang lain adalah berdasarkan penggunaannnya. Pakan berdasarkan penggunaannya dibagi atas bahan makanan konvensional (seperti bungkil kedelai dan dedak) dan nonkonvensional (seperti ampas nenas dan isi rumen).

\section{Kebutuhan Gizi Itik Petelur}

Telah banyak dilakukan penelitian tentang kebutuhan protein dan energi pada itik petelur lokal. Dari hasil-hasil penelitian tersebut, Sinurat (2000) menyusun rekomendasi kebutuhan gizi itik petelur pada berbagai umur (Ketaren, 2002). Rekomendasi yang tersedia saat ini dikelompokkan berdasarkan umur yaitu pakan starter untuk itik berumur $0-8$ minggu, pakan grower untuk itik berumur $9-20$ minggu, dan pakan petelur untuk itik berumur lebih dari 20 minggu yang ditunjukkan pada Tabel 1.

\begin{tabular}{|l|c|c|c|} 
Tabel 1 Kebutuhan Gizi Itik Petelur \\
\begin{tabular}{|l|c|c|c|}
\hline \multicolumn{1}{|c|}{ Gizi } & $\begin{array}{c}\text { Starter } \\
\mathbf{( 0 - 8} \\
\text { minggu) }\end{array}$ & $\begin{array}{c}\text { Grower } \\
\mathbf{( 9 - 2 0} \\
\text { minggu) }\end{array}$ & $\begin{array}{c}\text { Layer } \\
\mathbf{( > 2 0} \\
\text { minggu) }\end{array}$ \\
\hline Protein kasar (\%) & 18 & 16 & 18 \\
\hline Energi (kkal EM/kg) & 3100 & 2700 & 2700 \\
\hline Metionin (\%) & 0,37 & 0,29 & 0,37 \\
\hline Lisin (\%) & 1,05 & 0,74 & 1,05 \\
\hline $\mathrm{Ca}(\%)$ & 0,8 & 0,8 & 3 \\
\hline $\mathrm{P}(\%)$ & 0,6 & 0,6 & 0,6 \\
\hline
\end{tabular}
\end{tabular}

\section{Algoritma Genetika}

Genetic Algorithm (GA) atau Algoritma Genetika merupakan metode metaheuristic yang terinsipirasi 
dari proses seleksi natural (Agusta, 2018). GA secara keseluruhan merupakan proses yang terinsipirasi dari proses evolusi biologi yang berdasarkan teori evolusi Charles Darwin. Proses evolusi pada biologi terjadi pada Deoxyribonucleic Acid (DNA). DNA merupakan rantai atau sequence dari nucleotides yang membawa instruksi genetik yang digunakan untuk pertumbuhan, pengembangan, fungsi dan reproduksi dari suatu oranisme atau virus.

Setiap nucleotides mempunyai komposisi 1 diantara 4 nitrogen-containing nucleobases, yaitu cytosine $(\mathrm{C})$, guanine $(\mathrm{G})$, adenine $(\mathrm{A})$ dan thymine (T). Nucleotides inilah yang akan memberikan informasi penting bagi organisme. Organisme yang memiliki kategori baik atau buruk tergantung dari informasi DNA-nya. Setiap organisme yang mendapatkan organisme yang baik dari segi fisik atau phenotype maupun kemampuan tidak terlihat lainnya bisa didapatkan melalui perkawinan atau reproduksi antar organisme, proses ini disebut crossover. Suatu organisme juga dapat membentuk dirinya, beradaptasi atau ber-evolusi dari lingkungan atau yang disebut dengan proses selection dan mutation.

Proses umum pada GA terdiri dari proses umum evolusi yaitu selection, crossover dan mutation. Pada organisme proses ini terjadi pada DNA, namun pada GA hal tersebut dikodekan sesuai dengan konteks komputasi seperti dengan bilangan biner, float, integer maupun karakter, atau kombinatorial. Apabila menggunakan pengkodean biner, setiap faktor atau variabel dari masalah dikodekan kedalam bilangan biner, dimana setiap sekumpulan biner tersebut disebut individu. Proses evolusipun biasanya terjadi pada suatu kumpulan individu atau beradaptasinya terhadap lingkungan, kumpulan individu tersebut disebut dengan populasi. Maka setiap biner dalam individu dan populasi tersebutlah dilakukan proses selection, crossover dan mutation.

Output terbaik dari proses evolusi adalah individu yang baik atau dengan sebutan fitness organism. Dalam konteks GA, fitness tersebut disebut dengan fitness value. Kelebihan dari menggunakan algoritma genetika ini adalah fitness value yang dicari dapat menyelesaikan pada masalah global optimum dimana pada metode geometrik lebih sulit ditemukan atau sering terjebak di lokal optimum.

Tujuan dari algoritma genetika adalah mencari fitness value dari individu di suatu populasi. Proses keseluruhan merupakan proses iterasi dari generasi ke generasi, dimana setiap generasi menghasilkan keturunan atau offspring, dimana setiap keturunan mempunyai individu yang baik dibandingkan orangtua atau parentnya. Keturunan individu yang terbaik akan terpilih lagi menjadi parent pada generasi berikutnya. Proses ini terus menerus sampai fitness value dapat ditemukan. Terdapat 5 fase dalam algoritma genetika, yaitu sebagai berikut :

\section{a. Inisialisasi Populasi}

Proses dimulai dengan menginisialisasi beberapa individu atau disebut dengan populasi. Populasi merupakan kumpulan individu yang dimana akan diproses secara bersama dalam satu proses evolusi. Setiap individu adalah suatu solusi atau fitness value yang ingin dicari. Setiap individu merupakan sekumpulan dari gen atau disebut dengan kromosom. Dalam algoritma genetika, gen ini bisa berupa nilai biner, float, integer maupun karakter, atau kombinatorial. Pada Gambar 1 menunjukkan sekumpulan gen direpresentasikan dengan kode biner.

Kromosom merupakan representasi dari solusi. Operator genetika yang terdiri dari crossover dan mutation dapat dilakukan kedua-duanya atau hanya salah satu saja yang selanjutnya operator evolusi dilakukan melalui proses seleksi kromosom dari parent (generasi induk) dan offspring (generasi turunan) untuk membentuk generasi baru yang diharapkan akan lebih baik dalam memperkirakan solusi optimum, proses iterasi kemudian berlanjut sesuai dengan jumlah generasi yang telah ditetapkan (Prakoso, Ariyanto, \& Ririd, 2017).

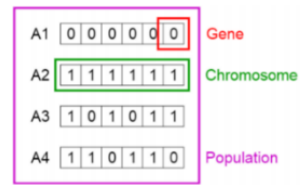

Gambar 1 Gen, Kromosom, dan Populasi

\section{b. Fungsi Fitness}

Fungsi fitness menghasilkan score atau fitness value yang dicari dari setiap individu. Fitness adalah nilai yang menandakan baik atau tidaknya suatu solusi. Fitness dijadikan pegangan untuk medapatkan nilai optimal pada algoritma genetika. Fungsi fitness yaitu merupakan alat ukur yang digunakan untuk mengevaluasi individu-individu pada setiap generasi.

\section{c. Seleksi}

Pada fase ini individu yang memiliki nilai paling fit dibiarkan untuk menjadi parent. Proses seleksi dipakai untuk memperoleh induk yang terbaik karena induk yang terbaik menghasilkan keturunan yang baik. Keturunan yang baik diketahui dengan nilai fitness yang tinggi. Terdapat beberapa metode seleksi pada induk, yaitu :

> Rank-based Fitness Assignment yaitu seleksi dengan mengurutkan nilai fitness yang dihasilkan oleh setiap individu.

> Roulette Wheel Selection adalah seleksi yang sederhana dimana individu ditetapkan dalam segmen secara berurutan sampai setiap individu memiliki nilai yang sama dengan fitness-nya.

> Stochastic Universal Sampling hampir sama dengan metode seleksi roulette wheel yang dimana satu individu diletakkan dalam segmen 
segaris sehingga memiliki nilai fitness yang sama perbedaannya pada stochastic ditambahkan pointer pada setiap individu yang ingin diseleksi.

$>$ Truncation Selection merupakan seleksi buatan yang digunakan untuk populasi yang sangat besar, individu yang diperoleh diurutkan sesuai nilai fitness. Seleksi sebagai indukan dilakukan pada nilai fitness terbaik.

$>$ Tournament Selection merupakan metode seleksi yang dimana nilai tour ditentukan untuk niai pada individu yang dipilih secara random. Individu yang akan mengalami seleksi hanya individu dengan nilai terbaik. Seleksi tournament ini memberikan kesempatan untuk semua individu yang sudah terpilih agar mempertahankan keragamannya.

\section{d. Crossover}

Individu yang dijadikan parent kemudian disilangkan untuk membentuk individu baru. Proses crossover dilakukan dengan probabilitas crossover yang ditentukan.

Teknik persilangan digunakan dengan menentukan crossover point didalam kromosom. Teknik persilangan yang ada antara lain single point crossover yakni teknik persilangan dengan cara memotong kromosom pada satu titik tertentu, multi point crossover yakni teknik pindah silang dengan cara memotong kromosom dengan banyak titik potong dikarenakan pada suatu masalah tertentu suatu individu terdiri dari sangat banyak gen misalkan 10000 gen sehingga memerlukan lebih dari satu titik pindah silang, dan uniform crossover yakni operasi pindah silang pola seragam untuk mempertahankan komposisi gen-gen tertentu pada suatu individu. Contoh dapat dilihat pada Gambar 2 dan 3 teknik persilangan menggunakan single point crossover. Pada Gambar 2 menunjukkan titik potong pada kromosom.

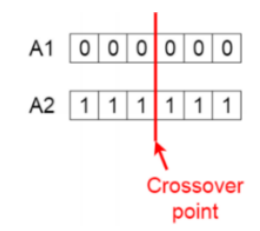

Gambar 2 Crossover point

Keturunan akan terlahir dengan menukar gen diantara parent sampai titik crossover point yang ditunjukkan pada Gambar 3. Setelah proses penukaran, keturunan baru yang dihasilkan dimasukkan ke populasi.

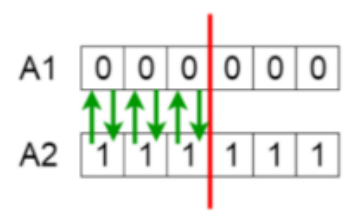

Gambar 3 Penukaran gen antar parent e. Mutasi

Proses mutasi pada algoritma genetika berfungsi untuk mengganti gen yang ada pada suatu individu yang dapat dilihat pada Gambar 4, diharapkan menghasilkan individu baru yang lebih baik. Proses mutasi biasanya dilakukan dengan probabilitas yang rendah. Mutasi dilakukan untuk mengendalikan keberagaman dalam populasi dan mencegah konvergensi yang terlalu dini.

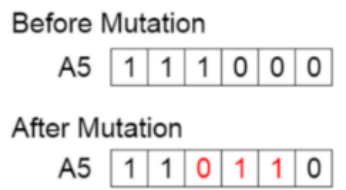

Gambar 4 Sebelum dan sesudah mutasi

Algoritma akan berhenti ketika populasi telah konergen, tidak lagi memproduksi keturunan yang signifikan dari generasi sebelumnya. Dengan kata lain algoritma genetika telah memberikan solusi dari masalah yang didefinisikan.

\section{Hasil}

\section{A) Ukuran Populasi}

Pada pengujian pertama dilakukan pengujian terhadap parameter ukuran populasi. Pengujian ukuran populasi dilakukan untuk mengetahui pengaruh ukuran populasi terhadap nilai fitness yang dihasilkan. Pengujian terhadap pengaruh ukuran populasi dilakukan dengan ukuran populasi sebanyak $5,15,35,70$ dan 210 dengan kombinasi $\mathrm{cr}=0,4$ dan $\mathrm{mr}=0,25$ dan jumlah generasi sebanyak 20. Untuk mendapatkan nilai rata-rata fitness setiap percobaan akan dilakukan sebanyak 5 kali. Tabel hasil uji coba ukuran populasi dapat dilihat pada Tabel 2 .

Tabel 2 Hasil Uji Coba Ukuran Populasi

\begin{tabular}{|l|c|c|c|c|c|c|}
\hline \multirow{2}{*}{$\begin{array}{c}\text { Ukuran } \\
\text { Populasi }\end{array}$} & $\mathbf{5}$ & $\mathbf{2}$ & $\mathbf{3}$ & $\mathbf{4}$ & $\mathbf{5}$ & $\begin{array}{c}\text { Rata- } \\
\text { Fitness }\end{array}$ \\
\cline { 2 - 7 } & & & & & & \\
\hline 5 & 1.337 & 1.151 & 0.737 & 2.674 & 2.938 & 1.767 \\
\hline 15 & 1.055 & 2.917 & 2.559 & 3.434 & 3.244 & 2.642 \\
\hline 35 & 3.420 & 1.152 & 3.226 & 2.942 & 2.792 & 2.706 \\
\hline 70 & 0.552 & - & 2.666 & 2.340 & 3.477 & 1.750 \\
\hline 210 & 0.676 & 1.650 & - & - & 2.575 & 0.469 \\
\hline
\end{tabular}

Berdasarkan hasil yang diperoleh pada uji coba ukuran populasi dapat dilihat bahwa ukuran populasi berpengaruh terhadap nilai fitness yang diperoleh dari perhitungan algoritma genetika. Solusi yang bagus didapatkan pada saat ukuran populasi sebanyak 35 dengan rata-rata fitness 2,706. Gambar 5 menunjukkan grafik hasil uji coba ukuran populasi, grafik mengalami kenaikan pada ukuran populasi 5 sampai dengan 35 dan kemudian menurun dari populasi 35 sampai 210. Ukuran populasi yang terlalu besar mengakibatkan area eksplorasi menjadi semakin sempit sehingga memungkinkan terjadi 
konvergensi dan waktu komputasi juga akan lama. Eksplorasi yang sempit menyebabkan pencarian solusi terbaik tidak berjalan dengan baik dan child yang dihasilkan nilai fitness-nya hampir sama dengan induknya (Sulistiyorini \& Mahmudy, 2015).

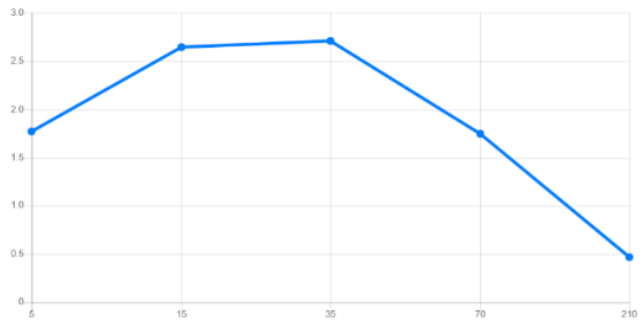

Gambar 5 Grafik Hasil Uji Coba Ukuran Populasi

\section{B) Kombinasi Crossover Rate dan Mutation Rate}

Pengujian kedua dilakukan dengan pengujian terhadap parameter kombinasi crossover rate (cr) dan mutation rate $(\mathrm{mr})$ yang digunakan dalam proses algoritma genetika. Pengujian kombinasi cr dan $\mathrm{mr}$ dilakukan untuk mengetahui pengaruh kombinasi cr dan $\mathrm{mr}$ terhadap nilai fitness yang dihasilkan. Kombinasi cr dan mr yang digunakan pada uji coba ini antara 0 sampai 0,9 dan masing-masing percobaan dilakukan sebanyak 5 kali yang akan diambil nilai rata-rata fitnessnya. Pada pengujian ini digunakan jumlah populasi terbaik dari pengujian sebelumnya sebanyak 35 populasi. Jumlah generasi yang digunakan sebanyak 20. Hasil uji coba kombinasi cr dan $\mathrm{mr}$ dapat dilihat pada Tabel 3.

Tabel 3 Hasil Uji Coba Kombinasi Cr dan $\mathrm{Mr}$

\begin{tabular}{|c|c|c|c|c|c|c|c|}
\hline \multirow[t]{2}{*}{$\mathrm{Cr}$} & \multirow[t]{2}{*}{$\mathbf{m r}$} & \multicolumn{5}{|c|}{ Nilai fitness percobaan ke- } & \multirow{2}{*}{$\begin{array}{l}\text { Rata- } \\
\text { rata } \\
\text { fitness }\end{array}$} \\
\hline & & 1 & 2 & 3 & 4 & 5 & \\
\hline 0 & 0.9 & 2.337 & 0.256 & 2.097 & 0.635 & 0.709 & 1.207 \\
\hline 0.1 & 0.8 & 2.244 & 3.005 & 2.309 & $\begin{array}{l}- \\
0.951\end{array}$ & 1.611 & 1.644 \\
\hline 0.2 & 0.7 & 3.004 & 3.644 & 2.045 & $\begin{array}{l}- \\
0.478\end{array}$ & 1.661 & 1.975 \\
\hline 0.3 & 0.6 & 2.597 & 1.489 & 3.738 & 3.075 & 0.552 & 2.290 \\
\hline 0.4 & 0.5 & 1.178 & 2.538 & 2.493 & 2.575 & 1.976 & 2.152 \\
\hline 0.5 & 0.4 & 2.666 & 2.702 & 2.489 & $\begin{array}{l}- \\
0.081\end{array}$ & 2.709 & 2.097 \\
\hline 0.6 & 0.3 & 3.477 & 2.790 & 1.151 & 0.737 & 3.226 & 2.276 \\
\hline 0.7 & 0.2 & 3.509 & 2.137 & 3.420 & 2.792 & 2.942 & 2.960 \\
\hline 0.8 & 0.1 & 3.359 & 2.559 & 3.434 & 1.647 & 3.530 & 2.906 \\
\hline 0.9 & 0 & 3.081 & 1.365 & 0.828 & 1.737 & 0.517 & 1.506 \\
\hline
\end{tabular}

Berdasarkan hasil yang diperoleh pada uji coba kombinasi cr dan $\mathrm{mr}$, kombinasi $\mathrm{cr}$ dan $\mathrm{mr}$ berpengaruh terhadap nilai fitness yang dihasilkan. Diketahui nilai fitness mengalami kenaikkan seiring dengan bertambahnya nilai cr dan berkurangnya nilai mr. Didapatkan nilai fitness tertinggi pada nilai cr dan $\mathrm{mr}$ sebesar 0,7 dan 0,2 dengan rata-rata nilai fitness sebesar 2,960. Crossover rate yang kecil dan mutation rate yang besar akan menurunkan kemampuan algoritma genetika untuk melakukan eksploitasi area optimum lokal. Dan tingkat crossover rate yang terlalu besar dan mutation rate yang terlalu kecil akan menurunkan kemampuan algoritma genetika untuk melakukan eksplorasi (Taufiq, Dewi, \& Mahmudy, 2017). Pada kasus ini eksploitasi yang dilakukan memiliki pengaruh yang signifikan dibandingkan dengan eksplorasinya. Hal ini dibuktikan pada grafik hasil pengujian $\mathrm{cr} \mathrm{mr}$ yang ditunjukkan oleh Gambar 6, bahwa dengan nilai cr yang semakin kecil dan nilai mr yang semakin besar membuat nilai rata-rata fitness yang diperoleh semakin menurun.

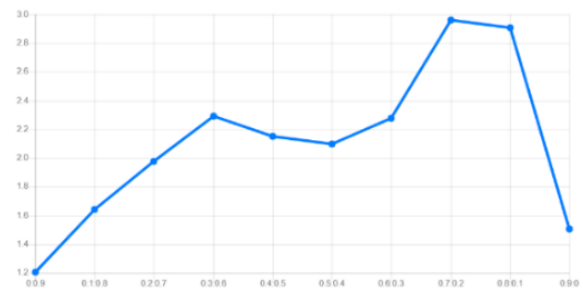

Gambar 6 Grafik Hasil Uji Coba Kombinasi Cr dan Mr

\section{C) Jumlah Generasi}

Pengujian terakhir adalah pengujian terhadap parameter jumlah generasi yang digunakan. Pengujian jumlah generasi dilakukan untuk mengetahui pengaruh jumlah generasi terhadap nilai fitnees yang dihasilkan. Untuk menguji jumlah generasi digunakan jumlah generasi sebanyak 10, 15, 20, 25 dan 30. Untuk mendapatkan hasil yang lebih valid maka setiap percobaan akan dilakukan sebanyak 5 kali untuk diambil nilai rata-rata fitnessnya. Pada percobaan ini digunakan populasi sebanyak 35 yang didapatkan dari percobaan sebelumnya pada uji coba ukuran populasi, dengan $\mathrm{cr}$ $=0,7$ dan $\mathrm{mr}=0,2$. Adapun tabel hasil uji coba jumlah generasi dapat dilihat pada Tabel 4.

\begin{tabular}{|l|l|l|l|l|l|l|}
\multicolumn{7}{c}{ Tabel 4 Hasil Uji Coba Jumlah Generasi } \\
\begin{tabular}{|l|l|l|l|l|} 
Jumlah \\
Generasi
\end{tabular} & $\mathbf{1}$ & $\mathbf{2}$ & $\mathbf{3}$ & $\mathbf{4}$ & $\mathbf{5}$ & $\begin{array}{l}\text { Rata- } \\
\text { rata } \\
\end{array}$ \\
\cline { 2 - 7 } & & & & & & \\
\hline 10 & - & 1.976 & 1.178 & 2.199 & 2.493 & 1.474 \\
& 0.476 & & & & & \\
\hline 15 & 2.709 & 3.075 & 1.611 & 0.552 & 3.738 & 2.337 \\
\hline 20 & 3.004 & 2.589 & 3.161 & 2.717 & 2.547 & 2.804 \\
\hline 25 & 2.337 & 0.709 & 1.489 & 2.097 & 0.256 & 1.378 \\
\hline 30 & - & 2.045 & - & 1.661 & 2.597 & 0.975 \\
& 0.478 & & 0.951 & & & \\
\hline
\end{tabular}

Pada hasil pengujian jumlah generasi diperoleh bahwa ukuran generasi berpengaruh terhadap nilai fitness yang dihasilkan dari perhitungan algoritma genetika. Dapat dilihat grafik mengalami kenaikan dan penurunan rata-rata nilai fitness. Gambar 7 menunjukkan grafik hasil uji coba jumlah generasi, grafik menunjukkan nilai rata-rata fitness tertinggi yaitu pada jumlah generasi sebanyak 20 dengan nilai rata-rata fitness sebesar 2,804. Dapat disimpulkan jumlah generasi yang tinggi belum tentu dikatakan 
generasi yang terbaik karena belum tentu nilai fitness yang diperoleh jauh lebih tinggi dari nilai fitness individu pada generasi sebelumnya. Hal ini bisa berlaku karena adanya sifat stochastic pada algoritma genetika (Taufiq, Dewi, \& Mahmudy, 2017). Stokastik disini adalah terkait hasil solusi yang didapatkan setiap kali melakukan percobaan yang baru selalu cenderung mendapatkan solusi yang berbeda. Sehingga bisa jadi solusi yang didapatkan saat ini tidak lebih baik jika dibandingkan dengan solusi yang didapatkan sebelumnya, dan sebaliknya (Lestari, et al., 2017).

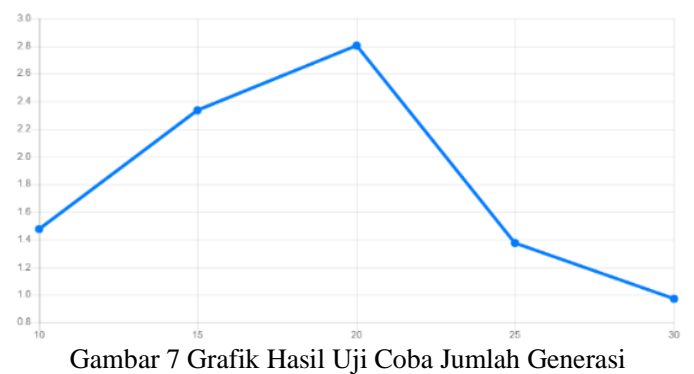

\section{Kesimpulan dan Saran}

Berdasarkan hasil pengujian dan pembahasan dari penentuan bahan makanan untuk itik petelur menggunakan algoritma genetika, maka diperoleh kesimpulan sebagai berikut: Algoritma genetika dapat diterapkan pada permasalahan penentuan bahan makanan untuk itik petelur dengan menggunakan representasi kromosom secara real code, teknik single point crossover, menggunakan random mutation serta penyeleksian dengan metode elitism selection pada generational replacement. Pada representasi kromosom secara real code setiap bahan pakan diwakili oleh sebuah angka dan angka tersebut merupakan sebuah gen yang ada pada sebuah kromosom. Setiap kromosom yang ada pada satu generasi merepresentasikan bahan pakan apa saja yang akan direkomendasikan; Untuk mengukur kualitas solusi terbaik pada permasalahan penentuan bahan makanan untuk itik petelur yaitu dengan melihat nilai fitness tertinggi. Fitness tertinggi adalah individu yang memiliki solusi yang paling baik berdasarkan sistem; Pengujian parameter algoritma genetika memiliki pengaruh terhadap nilai fitness yang dihasilkan. Pengujian pada parameter genetika dilakukan dengan mengkombinasikan crossover rate (cr) dan mutation rate (mr) yang terbaik terdapat pada kombinasi $\mathrm{cr}$ dan $\mathrm{mr} 0,7: 0,2$ dengan rata-rata nilai fitness 2,960. Ukuran populasi yang baik terdapat pada ukuran 35 dengan nilai fitness sebesar 2,706. Pengujian jumlah generasi dihasilkan fitness terbaik dengan nilai 2,804 dan terdapat pada jumlah generasi ke 20 .

Penelitian tentang penentuan bahan makanan untuk itik petelur menggunakan algoritma genetika dengan beberapa saran sebagai berikut: Pada program ini sebaiknya dapat melakukan pengelompokan jenis pakan secara otomatis sesuai dengan kebutuhan usia tertentu agar dapat mempermudah dalam melakukan pemilihan pakan; Untuk hasil dari sistem berupa rekomendasi bahanbahan makanan memenuhi nutrisi yang dibutuhkan akan lebih baik apabila ditambahkan pemberian berat dari setiap bahan serta harga.

\section{Daftar Pustaka}

Agusta, G. M. (2018). Algoritma Genetika. Bogor: Fakultas Matematika dan Ilmu Pengetahuan Alam Institut Pertanian Bogor.

Aribowo, A., Lukas, S., \& Gunawan, M. (2008). Penerapan Algoritma Genetika Pada Penentuan Komposisi Pakan Ayam Petelur.

Fakhiroh, D., Mahmudy, W. F., \& Indriati. (2017, Januari). Optimasi Komposisi Pakan Sapi Perah Menggunakan Algoritma Genetika. 1 .

Ilmu dan Teknologi Pakan Fakultas Peternakan IPB, T. (2012). Pengetahuan Bahan Makanan Ternak. Bogor: Ilmu dan Teknologi Pakan Fakultas Peternakan IPB.

Kementerian Kesehatan Republik Indonesia. (2017). Pedoman Metode Melengkapi Nilai Gizi Bahan Makanan Pada Tabel Komposisi Pangan Indonesia.

Ketaren, P. P. (2002). Kebutuhan Gizi Itik Petelur Dan Itik Pedaging. 12.

Lestari, A. R., Rofiqoh, U., Robbana, S., Nurjannah, W. E., Wulandari, U. L., \& Cholissidin, I. (2017). Penentuan Komposisi Bahan Makanan Bagi Penderita Gagal Ginjal Akut Dengan Algoritma Genetika. 12.

M, M., \& Subanar. (2017). Kajian Terhadap Beberapa Metode Optimasi. $V$.

Prakoso, A. B., Ariyanto, Y., \& Ririd, A. R. (2017). Optimasi Rute Lokasi Wisata Kota Malang Menggunakan Algoritma Gentika. 3.

Sampurna, I. P. (2013). Kebutuhan Nutrisi Ternak. Bali: Fakultas Kedokteran Hewan Universitas Udayana.

Sari, Y., Alkaff, M., Wijaya, E. S., Soraya, S., \& Kartikasari, D. P. (2018). Optimasi Penjadwalan Mata Kuliah Menggunakan Metode Algoritma Genetika Dengan Teknik Tornament Selection. 6.

Sulistiyorini, R., \& Mahmudy, W. F. (2015). Penerapan Algoritma Genetika Untuk Permasalahan Optimasi Distribusi Barang Dua Tahap. 5.

Suyanto. (2014). Artificial Intelligence. Informatika. Syururi, A., Hidayat, N., \& Dewi, R. K. (2019). Optimasi Komposisi Pakan Ternak Sapi Menggunakan Algoritme Genetika Simulated Annealing. 3.

Taufiq, M. N., Dewi, C., \& Mahmudy, W. F. (2017). Optimasi Komposisi Pakan Untuk Penggemukan Sapi Potong Menggunakan Algoritma Genetika. 1. 